\title{
Impact of trap barrier systems on rodent damage to upland rice cropping systems during bamboo masting events
}

Nikhil Chakmaa, d, ", Noor Jahan Sarker ${ }^{\mathrm{a}}$, Sohrab Uddin Sarker ${ }^{\mathrm{a}}$, Santosh Kumar Sarker ${ }^{b}$, Rokeya Begum Shafalib and Steven R. Belmain ${ }^{c}$

a Department of Zoology, University of Dhaka, Dhaka, Bangladesh, ${ }^{\mathrm{b}}$ Association for Integrated Development-Comilla, Comilla, Bangladesh

c Natural Resources Institute, University of Greenwich, Central Avenue, Kent ME4 4TB, United Kingdom

${ }^{\mathrm{d}}$ Current address: Food and Agriculture Organization of the United Nations (UNFAO), Dhaka, Bangladesh

*Corresponding author: Nikhil_forestry@yahoo.com

Key words: Rattus spp., Melocanna bamboo masting, ecologically-based rodent management, mautam, rodent outbreak

\section{Abstract}

Synchronous bamboo masting events are well-known to cause rodent population outbreaks. In South Asia, Melocanna baccifera undergoes semelparous masting every 58 years leading to large rodent outbreaks and nearly $100 \%$ crop losses. Current crop protection methods used to control rodent outbreaks are largely based on large-scale use of chronic and acute poisons. Non-chemical control methods, such as the use of trap barrier systems (TBS), could be effective in such outbreak situations. However, TBS is currently used in lowland irrigated rice cropping systems, and thus would need to be evaluated and adapted to the upland rice production systems commonly found in the areas affected by bamboo masting induced rodent outbreaks. In this study we carried out field trials over two cropping seasons (2009 and 2010) in the Ruma area of the Chittagong Hill Tracts, Bangladesh during an on going bamboo masting event. Rodent activity was measured through active burrow counting in TBS fenced and unfenced rice crop fields. No rodent activity was found in TBS fenced fields in 2009, with some limited activity in TBS fenced fields in 2010. In 2010, the mean number of active burrows in unfenced fields was 8.66 /ha, compared to $1.8 /$ ha in the TBS sites. Rodent damage was measured by counting rice tillers cut by rodents, with no damage observed in TBS fenced fields in 2009, with some limited damage in TBS fenced fields in 2010 (0.26\% damage), whilst unfenced 
field tiller damage was 3.2\% during 2009 and $1.77 \%$ during 2010 . The main rodent species captured by multi-capture traps in the TBS fences were Rattus rattus (70\%), Mus musculus (19\%), Rattus nitidus (5\%) and Cannomys badius (5\%). Rodent capture rates and crop damage were much lower than expected, which is arguably explained by an absence of rodent outbreaks in the selected communities, despite bamboo masting occurring in the surrounding forests around the rice fields. The using of TBS during the rodent outbreaks followed by Melocanna bamboo flowering is discussed in terms of the cost-benefits to prevent rodent damage in upland rice cropping systems.

\section{Introduction}

Several ecological and anthropogenic drivers have been identified that lead to large-scale rodent population outbreaks (Singleton et al., 2010a). Semelparous bamboo masting is one well-known driver of rodent outbreaks in a number of countries including Argentina, Peru, Brazil, China, India, Bangladesh, Myanmar, Laos and Madagascar (Janzen, 1976; Keeley and Bond, 1999; Singleton et al., 2010b). One of the most notorious bamboo masting events occurs on a 58-year cycle in the Himalayan foothill border areas of India, Bangladesh and Myanmar involving the bamboo species Melocanna baccifera (Chauhan and Saxena, 1986; Nadgauda, 2002; Nag, 1999). The flowering and masting event of $M$. baccifera in 1958 resulted in a regional famine where more than 10,000 people died of starvation in the Mizo hills alone, triggering a 20-year civil war and the establishment of the State of Mizoram within India in 1986 (Nag, 2008). The most recent bamboo masting event of $M$. baccifera in South Asia started in the States of Manipur, Tripura and Mizoram, India in 2005, with the synchronised bamboo flowering moving southwards each year, reaching the Chittagong Hill Tracts of Bangladesh in 2006 followed by Chin and Rakhine States of Myanmar in 2007 (Singleton et al., 2010b). Estimates of bamboo seed production during the event were approximately 80 tons per hectare (Janzen, 1976; Singleton et al., 2010b), providing ample food resources over a nine-month period each year for many seed predators, including rodents.

Severe damage to agricultural production from rodent outbreaks is well-documented from Australia, Asia and Africa (Singleton et al., 2010b; Swanepoel et al., 2017). However, 
crop protection technologies and strategies for mitigating rodent outbreaks are not very well-established or considered to be very effective (Singleton et al., 2005a). In Australia, aerial delivery of zinc phosphide over often greater than 300,000 hectares of wheat crops is the main strategy used to limit the destruction caused by outbreaks of Mus musculus (Brown et al., 2002). Rodent outbreaks in southern rice growing regions of Myanmar have led to regional bounty campaigns whereby government authorities pay farmers for the number of rodents killed and delivered to central collection points (Htwe et al., 2012; John, 2014). Rodent outbreaks in Tanzania are dealt with by a governmental department which freely distributes anti-coagulant poisons to farmers in affected areas (Mwanjabe et al., 2002). Although non-chemical methods of rodent control exist (Singleton et al., 2005b), these ecologically-based rodent management practices have largely been developed to deal with chronic rodent pest problems in agriculture as opposed to rodent outbreaks (Singleton et al., 2007). One successful non-chemical method of rodent control is the use of community-based trap barrier systems (TBS) to prevent rodent damage in lowland irrigated rice production systems (Jacob et al., 2010) and other cropping systems (Wang et al., 2017). A TBS consists of multiple-capture cage traps embedded within a plastic fence surrounding a rice crop that has been planted approximately two weeks earlier than the rest of the rice field, thus drawing rodents to the trap crop within the fenced area. Studies have found that a $50 \times 50$ m TBS enclosure can protect 10-15 ha of rice crop (Singleton et al., 2003). Efforts to use TBS in upland rice growing areas of Laos have been limited in success (Brown et al., 2017). However, a form of indigenous TBS is used by the Bawm community, one of the 13 Chittagong Hill Tribes of Bangladesh. Very few Bawm farmers construct bamboo fences around their upland rice crop with rodent kill traps embedded in the fence in order to prevent rodents gaining access to their rice field (Belmain, 2008; Belmain et al., 2010; Chakma et al., 2011). The fences are constructed of bamboo and contain dozens of traditional kill traps, which operate via a weightsensitive trigger that releases a log that crushes the rodent. However, each trap can kill only one rodent, after which it needs to be manually reset and rodents can migrate over the bamboo fence to the crop fields 
In this study we evaluated the use of TBS to control rodent damage in upland rice production during a rodent outbreak caused by bamboo flowering. The study spanned two cropping seasons and we also report on the main rodent pest species. We used active rodent burrow counting to quantify rodent activity and percentage cut rice tillers to estimate crop damage. Measurements of rodent activity (active burrow counting) and crop damage (cut rice tillers) were used to provide evidence that intervention of TBS could inform future policy decisions and farmer practices to sustainably manage rice crop damage caused during rodent outbreaks.

\section{Materials and Methods}

\subsection{Study site}

Farmer field research was carried out in three different villages (Basatlang, Munlai and Neweden) within Ruma Upazila (2202'57.41" N, 92024'36.21" E) of Bandarban District, Chittagong Hill Tracts, Bangladesh. These villages are located 10, 5 and $1.5 \mathrm{~km}$ away from central Ruma, respectively. Ruma is a mountainous region of $493 \mathrm{~km}^{2}$ of which 365 $\mathrm{km}^{2}$ consists of primary tropical forest. Smallholder agriculture, particularly shifting slash and burn crop rotation, is the main livelihood strategy, with farmers growing upland rainfed rice (1235 kg/ha on average) often intercropped with pumpkin, maize, cucumber, chilli, arum, potatoes, banana and other green vegetables (Belmain et al., 2010). Bamboo and other forest products are also economically and culturally important. During masting events, bamboo seeds provide a prolonged food resource to rodents promoting high rodent population growth over several generations (Jaksic and Lima, 2003; Sage et al., 2007). The most recent mautam event reached the Ruma area during 2007 and continued over three cropping seasons up until 2010. Rodent trapping, the use of trap barrier systems and crop damage assessments were carried out during 2009 and 2010 in order to understand the relationship between rodent outbreaks, crop damage and potential mechanisms to mitigate crop damage.

\subsection{Trap barrier system}

In 2009, two farmer fields were selected in each of the three villages (Basatlang, Munlai and Neweden), providing six fields. Due to slash and burn practices, different fields were 
used during the 2009 and 2010 cropping seasons. The individual farmers involved and community leaders provided written consent for the trials to be carried out on their land. Crop fields were 1-3 km from the village centre and were surrounded by Melocanna bamboo forest. Farmers sowed their rice crops soon after the first pre-monsoon rain in late April and harvested their crops from August to October, with harvest time dependent on crop variety. Rice varieties were indigenous upland varieties, with lower yielding varieties harvested in August and higher yielding varieties harvested in October. One field in each village location was surrounded with a trap-barrier fence containing multicapture rodent traps (Fig. 1a \& b), whilst the other field remained unfenced. The fences were all built during the seedling stage of the rice crop. The live multi-capture traps were locally made from galvanised steel and wire $(600 \times 240 \times 240 \mathrm{~mm})$. The fencing was made of wooden stakes and plastic sheeting, where the bottom of the plastic fence was buried approximately $25 \mathrm{~cm}$ deep in the ground to prevent rodents from burrowing under the fence (Aplin et al., 2003; Singleton, 2002). Fence height above ground was at least one metre. The multi-capture traps were all positioned inside the enclosure with the entrance facing outwards, at $10 \mathrm{~m}$ intervals. Farmer fields varied in size from 0.40 to $2.0 \mathrm{ha}$, with each TBS fence surrounding the entire field. In 2009, a total of 66 multi-capture traps were set in the three TBS fields (28 in Neweden, 20 in Munlai and 18 in Basatlang). In 2010, 59 multi-capture traps were used (20 in Neweden, 20 in Munlai and 19 in Basatlang) where the number of traps reflects the variable size of the field perimeter. Banana mixed with flour, bamboo seeds or dried fish were used alternately as rodent bait in the traps, with fresh bait placed daily. Multi-capture traps were checked daily throughout the cropping season in the morning with all captures killed and recorded, noting species, sex and breeding condition.

During 2009 only, a single indigenous fence made of bamboo surrounding a rice field at Neweden was selected to allow for a comparison of crop damage between the two fence types. These traditional bamboo fences are believed to prevent rodents entering rice fields and are made from woven bamboo where kill traps are embedded within the fence and use a trigger mechanism that aims to squash the rodent (Fig. 1c). 


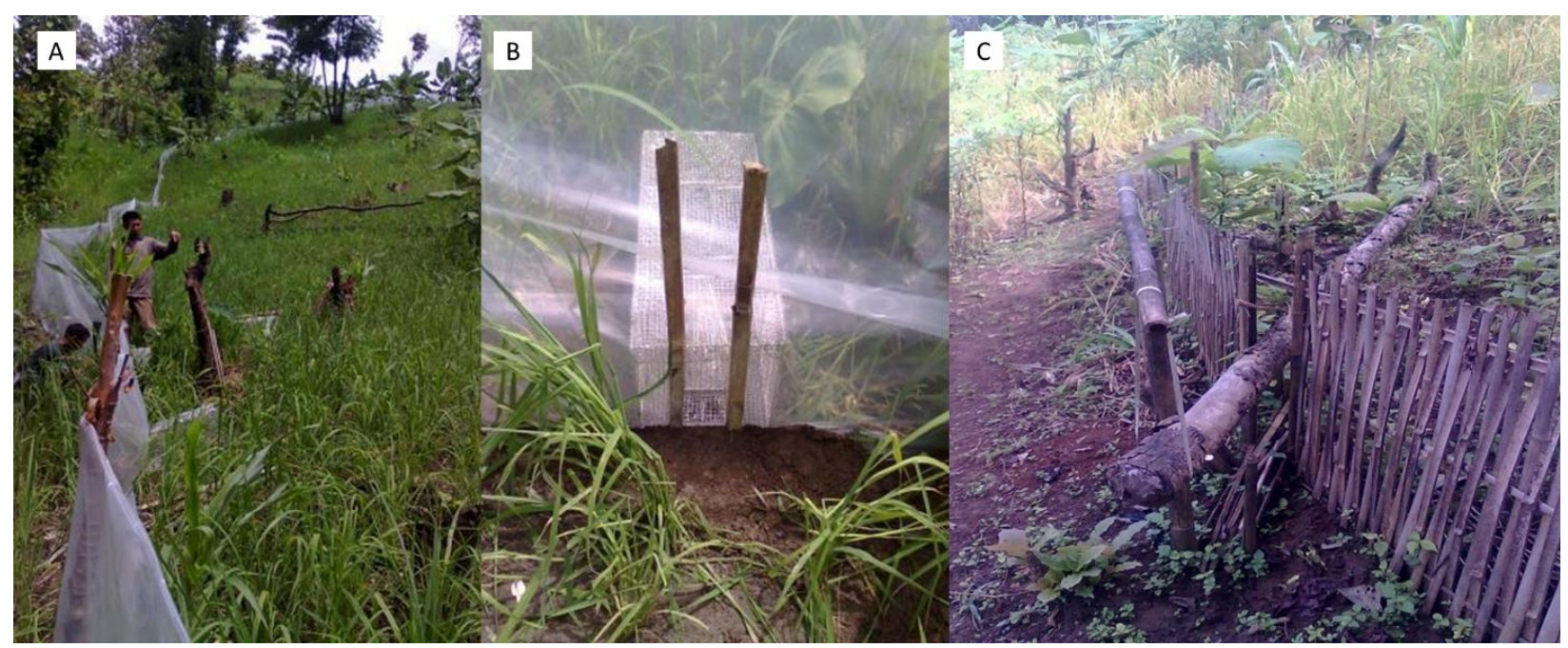

Fig. 1. Rodent trap barrier system showing A) plastic fence around perimeter of rice field B) multi-capture trap embedded in TBS fence and C) example of an indigenous trap barrier fence made from bamboo showing the local kill trap mechanism.

\subsection{Rodent damage assessment}

As all cropping areas in the region are on steep slopes, crop damage data were collected from three different locations in each of the six crop fields, i.e. near the top of the hill, the middle of the hill and near the bottom of the hill. Rodent damage to rice was assessed using an established quadrat method (Aplin et al., 2003) with a $1 \mathrm{~m}^{2}$ plot. Two quadrats were randomly placed in each of the three field locations (avoiding $5 \mathrm{~m}$ around the field edge), thus providing six quadrats per crop field ( 2 quadrats $\times 3$ field positions $=6$ replicates). Damage assessment was carried out at five rice crop growth stages: tillering (40-55 days after sowing), booting/flowering (70-80 days after sowing), pre-ripening (95 105 days after sowing), ripening (110-120 days after sowing) and harvest (130-140 days after sowing). Each quadrat was marked with bamboo sticks to identify the sample plot easily. Total cut and uncut tillers were counted within each quadrat, i.e. both old and fresh cut tillers were counted each time.

\subsection{Active rodent burrow counting}

Active rodent burrows were counted at two crop times, 1-2 weeks before harvesting and 1-2 weeks after harvesting of 2010 rice cropping season. Methods described by Aplin et al., (2003) were followed, and involved surveying each field for rodent burrows, closing these up with dirt, marking each closed burrow with a marker flag and revisiting each 
burrow to observe whether it remained closed or had been opened by a rodent, thus being an active burrow. On each visit, all re-opened burrows were closed again. All marked burrows were revisited at 1, 4 and 7 days after their original closure to record the number of opened, active burrows.

\subsection{Data analysis}

Rodent trap success was calculated on a daily basis, dividing the number of rodents caught by the number of traps set each day. Mean monthly trap success represents the average $( \pm S E)$ percent daily trap success rate for each month. Active burrows and rodent damage data are expressed as percentage values. Active rodent burrows data were analysed using the independent sample t-test and ANOVA and rodent damage data were analysed using a General Linear Model (GLM) to observe differences between TBS and unfenced crops. SPSS version 19 was used to analyse the data with post-hoc Bonferroni and mean values significance set at $p<0.05$.

\section{Results}

\subsection{Rodent captures at TBS fields}

Approximately $70 \%$ of all rodent captures were Rattus rattus, followed by Mus musculus (15\%), Rattus nitidus (5\%) and Cannomys badius (9\%). The overall trap success rate was $0.54 \%$ in 2009 and $0.42 \%$ in 2010 (Table 1). An analysis of variance indicated there were significant differences in the number of rodents captured across months (ANOVA, F 5, 11 $=9.74, p=0.001)$ and the highest capture rate was found in August $(1.44 \%)$ followed by July $(1.30 \%)$, suggesting there was a reduced number of rodents caught during the early harvest crop stage (Fig. 2). However, using 2009 data, there was no difference according to village locations (ANOVA, $F_{2,14}=0.29, p=0.75$ ). In 2010 , an analysis of variance indicated there were also significant differences in rodent capture rates across months (ANOVA, F 5, $12=9.28, p=0.001$ ) and the highest capture rate was found in September (1.54\%) followed by October ( $0.65 \%)$. Using 2010 data there was no difference according to village locations (ANOVA, $F_{2,6}=4.20, p=0.72$ ). 
Table 1: Rodent species composition according to rice crop field location and year when captured by multi-capture traps embedded in a trap barrier fence.

\begin{tabular}{lcccccc}
\hline Species & & 2009 & & & 2010 & \\
& Munlai & Neweden & Basatlang & Munlai & Neweden & Basatlang \\
\hline Cannomys badius & & 2 & 1 & & 1 & 3 \\
Mus musculus & 4 & 5 & & & 2 & \\
Rattus nitidus & 8 & 1 & 1 & 1 & & 1 \\
Rattus rattus & 12 & 11 & 8 & 3 & 10 \\
Total & $\mathbf{1 2}(\mathbf{0 . 4 7 )}$ & $\mathbf{2 0}(\mathbf{0 . 5 5 )}$ & $\mathbf{1 3 ( 0 . 6 0 )}$ & $\mathbf{9 ( 0 . 3 9 )}$ & $\mathbf{6 ( 0 . 2 5 )}$ & $\mathbf{1 4}(\mathbf{0 . 6 4 )}$ \\
\hline
\end{tabular}

Total number caught over rice cropping season followed by percentage of trap success in brackets.

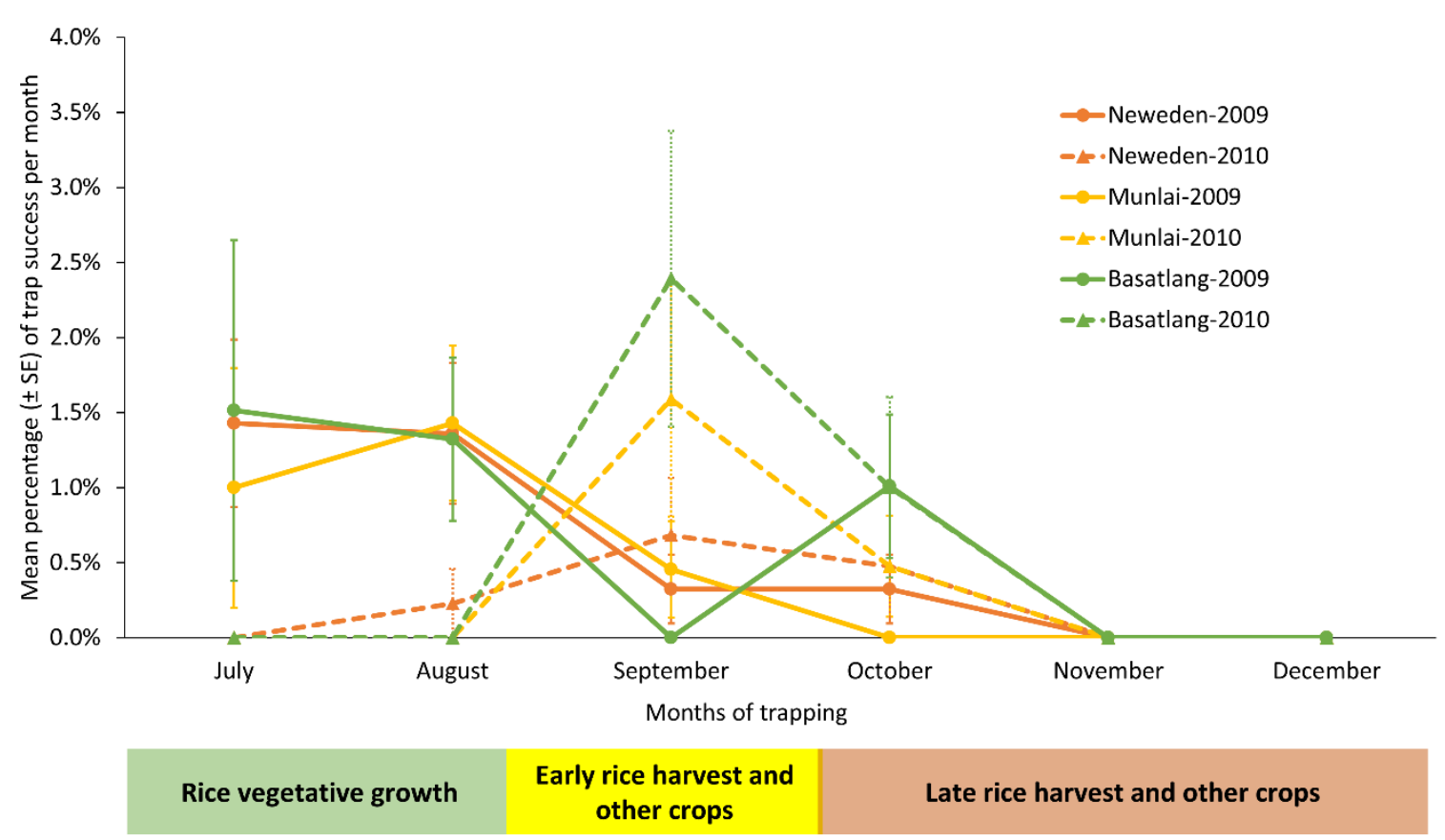

Fig. 2. Mean monthly trap success at the different trap barrier system (TBS) fields at Munlai, Neweden and Basatlang in 2009 and 2010

\subsection{Rodent damage to rice tillers}

There were no differences observed in number of tillers or percentage of tillers cut by rodents according to the location of quadrats at the top, middle or bottom of rice fields both in 2009 (GLM, $F_{2,87}=1.847, p=0.164$ ) and in 2010 ( $G L M, F_{2,87}=0.179, p=0.836$ ). We, therefore, pooled tiller count data across all six quadrats per field. TBS fencing around rice fields reduced the rate of tiller damage by rodents, and no cut tillers were 
observed to rice fields surrounded by the TBS in 2009, whilst the TBS reduced tiller damage by $50 \%$ in 2010 in comparison to the unfenced rice fields (t-test, $t_{76}=3.56$, $p=0.001$, Table 2). We did not observe cut tillers at the single indigenous bamboo fence throughout the 2009 cropping season.

Table 2: Rice tiller damage (Mean \pm SE) in fenced and unfenced sites during 2009 and 2010 cropping seasons.

\begin{tabular}{lcccccc}
\hline Rice field fence type & $\begin{array}{c}2009 \\
\text { Total tillers } \\
\left(1 \mathrm{~m}^{2}\right)\end{array}$ & $\begin{array}{c}\text { Tillers cut by } \\
\text { rodents } \\
\left(1 \mathrm{~m}^{2}\right)\end{array}$ & $\begin{array}{c}\text { Tiller } \\
\text { damage }(\%)\end{array}$ & $\begin{array}{c}\text { Total tillers } \\
\left(1 \mathrm{~m}^{2}\right)\end{array}$ & $\begin{array}{c}\text { Tillers cut by } \\
\text { rodents } \\
\left(1 \mathrm{~m}^{2}\right)\end{array}$ & $\begin{array}{c}\text { Tiller } \\
\text { damage }(\%)\end{array}$ \\
\hline TBS $(\mathrm{n}=6)$ & $116.1 \pm 3.97$ & 0 & 0 & $136.2 \pm 3.08$ & $0.35 \pm 0.08$ & 0.26 \\
Bamboo fence $(\mathrm{n}=1)$ & $79.1 \pm 4.76$ & 0 & 0 & & No data & \\
Unfenced $(\mathrm{n}=6)$ & $109.6 \pm 2.99$ & $3.5 . \pm 0.69$ & 3.2 & $135.2 \pm 2.53$ & $2.4 \pm 0.24$ & 1.77 \\
\hline
\end{tabular}

Focussing on the spatio-temporal dynamics of tiller damage in the unfenced rice fields, significant differences were observed across rice crop growth stages in 2009 (GLM, F 4, $85=4.923, p=0.001)$ and in $2010\left(G L M, F_{4,85}=13.01, p=0.001\right.$. A post-hoc Bonferroni analysis showed there was a significant increase in tiller damage between the flowering and harvest stages in $2009(p=0.034)$ and in $2010(p=0.026)$ as well as significantly more crop damage in 2009 compared to 2010 at the harvest stage ( $p=0.04$, Fig. 3). An analysis of variance on cut tillers across the three village locations for unfenced rice crop fields showed that there were no differences within each year of 2009 (GLM, F 2,89 $=2.967$, $p=0.0570$ ) and 2010 (GLM, $\left.F_{2,87}=1.631, p=0.202\right)$; however, between years there was a significant difference in rodent damage in Munlai and Basatlang ( $p=0.02$, Fig. 4), with lower damage in the 2010 cropping season. 


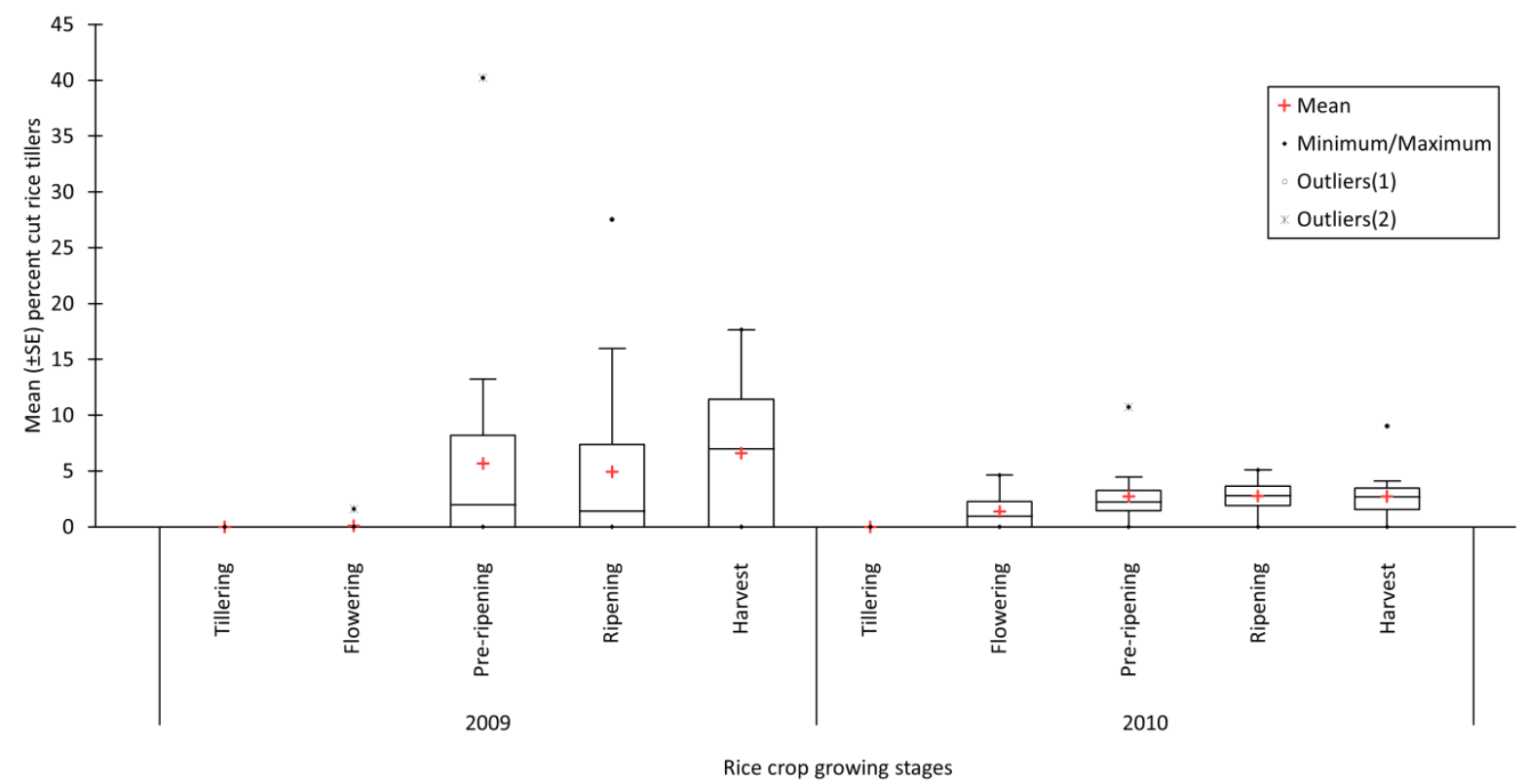

Fig. 3. Box plot showing the percent of rice tillers cut by rodents across three unfenced rice fields at crop growing stages in 2009 and 2010.

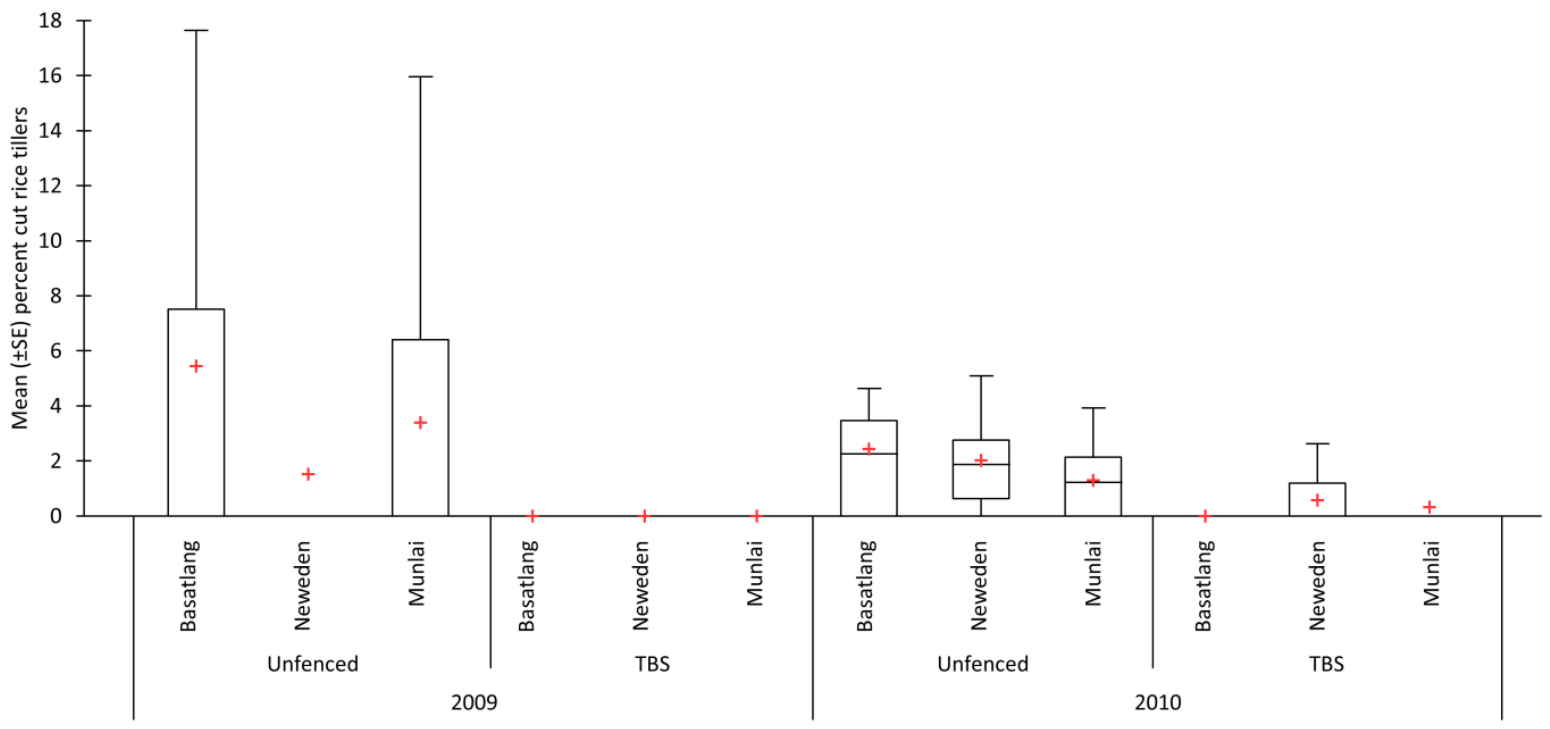

Fig. 4. Box plot showing the percent of rice tillers cut by rodents between unfenced and TBS rice fields in different village locations in 2009 and 2010

\subsection{Rodent burrow counts}

Active rodent burrows were found within all rice crop fields, whether they were fenced or unfenced (Table 3). Within unfenced fields, $84 \%$ of burrows at pre-harvest and $82 \%$ of 
burrows at post-harvest were found to be active burrows. Whereas for TBS fields, $36 \%$ of burrows at pre-harvest and $37 \%$ of burrows at post-harvest were found to be active burrows. The total number of active burrows in TBS fenced fields was significantly lower than the mean total number of active burrows in unfenced fields (GLM, $F_{1,10}=15.423$, $\mathrm{p}=0.003$ ). However, there was no significant differences of active burrows between preharvest and post-harvest crop assessments $\left(\mathrm{GLM}, \mathrm{F}_{1,10}=0.431, \mathrm{p}=0.526\right)$.

Table 3: Mean number and percentage of active rodent burrows across three village locations in 2010 cropping season comparing unfenced and TBS fenced rice crop fields.

\begin{tabular}{|l|c|c|c|c|c|c|c|c|c|c|}
\hline \multirow{2}{*}{$\begin{array}{l}\text { Rice field } \\
\text { fence } \\
\text { type }\end{array}$} & $\begin{array}{c}\text { Burrow } \\
\text { count } \\
\text { day 0 }\end{array}$ & $\begin{array}{c}\text { Active } \\
\text { burrows } \\
\text { day 1 }\end{array}$ & $\begin{array}{c}\text { Active } \\
\text { burrows } \\
\text { day 4 }\end{array}$ & $\begin{array}{c}\text { Active } \\
\text { burrows } \\
\text { day 7 }\end{array}$ & $\begin{array}{c}\text { Active } \\
\text { burrows } \\
\text { per ha }\end{array}$ & $\begin{array}{c}\text { Burrow } \\
\text { count } \\
\text { day 0 }\end{array}$ & $\begin{array}{c}\text { Active } \\
\text { burrows } \\
\text { day 1 }\end{array}$ & $\begin{array}{c}\text { Active } \\
\text { burrows } \\
\text { day 4 }\end{array}$ & $\begin{array}{c}\text { Active } \\
\text { burrows } \\
\text { day 7 }\end{array}$ & $\begin{array}{c}\text { Active } \\
\text { burrows } \\
\text { per ha }\end{array}$ \\
\hline $\begin{array}{l}\text { Unfenced } \\
(\mathrm{n}=6)\end{array}$ & 10.33 & $\begin{array}{c}2.67 \\
(25.8) *\end{array}$ & $\begin{array}{c}3.33 \\
(32.3)\end{array}$ & $\begin{array}{c}2.67 \\
(25.8)\end{array}$ & 8.66 & 15.00 & $\begin{array}{c}5.67 \\
(37.8)\end{array}$ & $\begin{array}{c}3.33 \\
(22.2)\end{array}$ & $\begin{array}{c}3.33 \\
(22.2)\end{array}$ & 12.33 \\
\hline $\begin{array}{l}\text { TBS } \\
(\mathrm{n}=6)\end{array}$ & 7.33 & $\begin{array}{c}0.67 \\
(9.1)\end{array}$ & $\begin{array}{c}1.67 \\
(22.7)\end{array}$ & $\begin{array}{c}0.33 \\
(4.5)\end{array}$ & 2.66 & 8.00 & $\begin{array}{c}1.67 \\
(20.8)\end{array}$ & $\begin{array}{c}1.00 \\
(12.5)\end{array}$ & $\begin{array}{l}0.33 \\
(4.2)\end{array}$ & 3.00 \\
\hline
\end{tabular}

*Mean number followed by percent in brackets. Active burrow counting was carried out over a period of seven days one week before crop harvest and one week after crop harvest.

\section{Discussion}

Rodent trapping from the TBS suggests that the number of rodent captures was low during the early stages of rice growth compared to the time of rice harvest. Crop damage assessment at TBS and unfenced crop fields suggest that TBS can be an appropriate method to reduce crop damage during the rodent outbreaks followed by bamboo masting. Although we did not find cut tillers at the single indigenous bamboo fence, it was observed that rodents can migrate into the bamboo fenced crop field through climbing over the fence or through gaps in the woven bamboo. Rodent damage was observed at TBS fields, although efforts were made to remove rats from each TBS field at the time of land preparation and TBS fence construction. Our active burrow count data suggest that either some rodents remained inside the TBS enclosures and/or somehow gained access to fields during the 2010 cropping season. As we are unable to discount either explanation, future research should attempt to confirm the presence of rodents over the cropping season by carrying out periodic burrow counting and/or rodent trapping soon after TBS 
fences are constructed. For example, some of the multi-capture traps could be reversed to capture rodents within the field. Burrow count data around harvest time suggest the numbers of rodents inside TBS fences was relatively lower compared to unfenced fields, and this is confirmed by lower rates of rice crop damage observed through counting cut rice tillers.

Due to ongoing bamboo masting in the Ruma region at the time of the field studies, it was expected that high numbers of rodents would be captured in the multi-capture traps. Bamboo masting events in the region are documented to lead to $100 \%$ crop losses and regional famine caused by large outbreaks of rodents feeding on bamboo seeds and breeding over several months before rice crops are typically harvested (Belmain et al., 2010). Bamboo masting was clearly present in the nearby forested areas around the selected cropping areas. Despite this, farmers in the Ruma area did not experience widespread crop losses during 2009 and 2010 as was occurring in other parts of the Chittagong Hill Tracts (Belmain, 2008). Evidence collected during the bamboo masting event from India, Myanmar and Bangladesh (Singleton et al., 2010b) suggests rodent population outbreaks can be highly localised, with some farmers losing all their crops whilst other farmers nearby avoid significant rodent damage. Several reasons for these differences have been proposed, such as differences in the abundance of bamboo in different forest localities, the degree of synchrony of the bamboo masting, the effect of altitude on bamboo flower initiation, planting early-ripening rice crop varieties and the timing of crop sowing and harvesting that can enable farmers to harvest their crops before outbreaks occur (Aplin and Lalsiamliana, 2010). Our crop damage data would confirm reports from farmers in Ruma that rodent outbreaks were not widespread in the villages of Neweden, Munlai and Basatlang, but that some farmers, particularly those living in relatively inaccessible villages further away from Ruma and at higher altitude, experienced rodent outbreaks and severe crop losses. Our data on the number of rodents captured in the multi-capture traps was generally quite low, and, similarly, rodent damage in unfenced fields was observed to be low. Although we expected trap success and crop damage to be higher due to the bamboo masting event, our data do agree with the general 
outcomes that rodent outbreaks were not affecting the farmers in our selected village locations.

Trap success from the multi-capture traps embedded in the TBS fences was lower than expected and particularly if this is compared to capture rates observed in TBS fences that are used in lowland irrigated rice cropping systems (Brown et al., 2017, 2006; Singleton et al., 1998). Low capture rates in the upland fields of our study are partly explained by differences in agro-ecosystems where field cropping areas are generally small (0.5 to 3 hectares), surrounded by primary forest and grown over a single rainy season each year with a significant fallow period. This is in contrast to lowland irrigated rice cropping, which is usually conducted over much larger land areas ( $>5 \mathrm{ha}$ ) and where rodent pest numbers can be facilitated by growing 2-3 crops per annum. Rodent trap success in our study is similar to that observed in upland areas of Laos (Brown and Khamphoukeo, 2010; Jäkel et al., 2017, 2016) and other forest habitats in Uganda, Argentina and Madagascar (Kasangaki et al., 2003; Milesi et al., 2017; Stephenson, 1994). Trap success patterns were notably different between 2009 and 2010 cropping seasons, with the highest success peaking in August during 2009 and peaking in September during 2010. These differences are largely explained by an earlier start to the monsoon rains in 2009 compared to 2010, resulting in slightly later harvests during 2010 (Holland et al., 2015). This suggests crop harvesting appears to increase the rate of capture of rodents and may reflect that this is typically when rodent populations are generally at their highest and/or most mobile (Cavia et al., 2005; Monadjem et al., 2011).

Our data suggest that TBS fences can help prevent rodent damage to upland rice cropping systems. However, due to the absence of rodent outbreaks in the study area at the time of field work, we are unable to say whether a TBS, as constructed, would be effective under very high rodent population pressure caused by bamboo masting events, e.g. perhaps more multi-capture traps would need to be embedded in the fence. The present study did not consider a cost-benefit analysis of building and maintaining a TBS. The cost of establishment of an individual TBS was approximately USD 70 including cost for rat traps, plastic sheeting, timber posts, string, staples, transport and labour. Due to 
the hilly terrain and remote areas of farmer fields, the cost of TBS construction is more than three times higher in terms of labour and transport when compared to their use in lowland irrigated rice production systems. Considering that bamboo masting events and the subsequent rodent population outbreaks can result in 100\% crop loss, any costbenefit assessment must take account of the severity of crop loss suffered. As our study has experienced, it is not always easy to predict in advance whether rodent outbreaks will affect specific farms. Although many farm families in the region did lose $100 \%$ of their crops, falling into severe debt and food insecurity, it is not clear whether the investment costs of TBS would be economically affordable for individual farmers when the risk of crop loss from rodent outbreaks remains unpredictable. As it is not possible for the costs of TBS to be shared by a group of farmers, as occurs in lowland irrigated farming systems (Palis et al., 2011), local government authorities may need to consider subsidising the construction of TBS during bamboo masting events. A TBS subsidy scheme could prevent rodent losses, and reduce the need for government responses to distribute food aid during such crises.

\section{Acknowledgements}

We would like to thank the following for technical support in the field: Nazmul, Harun, Sang, Lal lian, Ate, Lal Van, and Asang. We acknowledge the administrative support from Mr. Azad and all staff from Association for Integrated Development-Comilla. This project was funded by the World Bank through the Krishi Gobeshona Foundation, Bangladesh. The funder had no role in study design, data collection and analysis, decision to publish, or preparation of the manuscript. The authors declare that they have no conflict of interest.

\section{References}

Aplin, K., Lalsiamliana, J., 2010. Chronical and impacts of the 2005-09 mautam in Mizoram, in: Singleton, G.R., Belmain, S.R., Brown, P.R., Hardy, B. (Eds.), Rodent Outbreaks : Ecology and Impacts. IRRI, pp. 13-47.

Aplin, K.P., Brown, P.R., Jacob, J., Krebs, C.J., Singleton, G.R., 2003. Field methods for rodent studies in Asia and the Indo-Pacific. Australian Centre for International Agricultural Research, Canberra, Australia.

Belmain, S.R., 2008. Bamboo Flowering, Rodent Outbreaks and Food Security: Rodent ecology, pest management, and socio-economic impact in the Chittagong Hill 
Tracts, Bangladesh, UNDP. Dhaka.

https://doi.org/10.13140/RG.2.2.20184.55047

Belmain, S.R., Chakma, N., Sarker, N.J., Sarker, S.U., Sarker, S.K., Kamal, N.Q., 2010.

The Chittagong story: studies on the ecology of rat floods and bamboo masting,

in: Singleton, G.R., Belmain, S.R., Brown, P.R., Hardy, B. (Eds.), Rodent

Outbreaks: Ecology and Impacts. IRRI, pp. 49-63.

Brown, P.R., Chambers, L.K., Singleton, G.R., 2002. Pre-sowing control of house mice (Mus domesticus) using zinc phosphide : efficacy and potential non-target effects. Wildl. Res. 29, 27-37. https://doi.org/10.1071/WR01023

Brown, P.R., Douangboupha, B., Htwe, N.M., Jacob, J., Mulungu, L., My Phung, N.T., Singleton, G.R., Stuart, A.M., 2017. Control of rodent pests in rice cultivation, in: Achieving Sustainable Cultivation of Rice. Burleigh Dodds Science Publishing, pp. 343-376. https://doi.org/10.19103/AS.2016.0003.24

Brown, P.R., Khamphoukeo, K., 2010. Changes in farmers' knowledge, attitudes and practices after implementation of ecologically-based rodent management in the uplands of Lao PDR. Crop Prot. 29, 577-582.

https://doi.org/10.1016/J.CROPRO.2009.12.025

Brown, P.R., Tuan, N.P., Singleton, G.R., Ha, P.T.T., Hoa, P.T., Hue, D.T., Tan, T.Q., Tuat, N. Van, Jacob, J., Müller, W.J., 2006. Ecologically based management of rodents in the real world: Applied to a mixed agroecosystem in Vietnam. Ecol. Appl. 16, 2000-2010. https://doi.org/10.1890/1051-

0761(2006)016[2000:EBMORI]2.0.CO;2

Cavia, R., Villafañe, I.E.G., Cittadino, E.A., Bilenca, D.N., Miño, M.H., Busch, M., 2005. Effects of cereal harvest on abundance and spatial distribution of the rodent Akodon azarae in central Argentina. Agric. Ecosyst. Environ. 107, 95-99. https://doi.org/10.1016/J.AGEE.2004.09.011

Chakma, N., Belmain, S.R., Sarker, N.J., Sarker, S.U.S.K.U., Kamal, N.Q.Q., Sarker, S.U.S.K.U., 2011. Rat floods and water floods : the ecological and sociological dynamics of rodent management in Bangladesh, in: 8th European Vertebrate Pest Management Conference. pp. 171-173. https://doi.org/10.5073/jka.2011.432.094

Chauhan, N.S., Saxena, R.N., 1986. Phenomenon of bamboo flowering and associated increase in rodent population in Mizoram. J. Bombay Nat. Hist. Soc. 82, 644647.

Holland, E.P., James, A., Ruscoe, W.A., Pech, R.P., Byrom, A.E., 2015. Climate-Based Models for Pulsed Resources Improve Predictability of Consumer Population Dynamics: Outbreaks of House Mice in Forest Ecosystems. PLoS One 10, e0119139. https://doi.org/10.1371/journal.pone.0119139

Htwe, N.M., Singleton, R., Nelson, A.D., 2012. Can rodent outbreaks be driven by major climatic events ? Evidence from cyclone Nargis in the Ayeyawady Delta , Myanmar. Pest Manag. Sci. 8. https://doi.org/10.1002/ps.3292

Jacob, J., Sudarmaji, Singleton, G.R., Rahmini, Herawati, N.A., Brown, P.R., 2010. Ecologically based management of rodents in lowland irrigated rice fields in Indonesia. Wildl. Res. 37, 418. https://doi.org/10.1071/WR10030 
Jäkel, T., Mouaxengcha, K., Douangboupha, B., 2017. Efficiency of rodent control in upland rice and potential of forecasting chronic rodent infestation in Northern Laos. Crop Prot. 98, 211-221. https://doi.org/10.1016/J.CROPRO.2017.04.003

Jäkel, T., Mouaxengcha, K., Nuber, U., Douangboupha, B., 2016. Integrated rodent management in outbreak-prone upland rice growing areas of Northern Laos. Crop Prot. 79, 34-42. https://doi.org/10.1016/J.CROPRO.2015.10.003 Jaksic, F.M., Lima, M., 2003. Myths and facts on ratadas: Bamboo blooms, rainfall peaks and rodent outbreaks in South America. Austral Ecol. 28, 237-251.

Janzen, D.H.H., 1976. Why Bamboos Wait So Long to Flower. Annu. Rev. Ecol. Syst. 7, 347-391. https://doi.org/10.1146/annurev.es.07.110176.002023

John, A., 2014. Rodent outbreaks and rice pre-harvest losses in Southeast Asia. Food Secur. 6, 249-260. https://doi.org/10.1007/s12571-014-0338-4

Kasangaki, A., Kityo, R., Kerbis, J., 2003. Diversity of rodents and shrews along an elevational gradient in Bwindi Impenetrable National Park, south-western Uganda. Afr. J. Ecol. 41, 115-123. https://doi.org/10.1046/j.13652028.2003.00383.x

Keeley, J.E., Bond, W.J., 1999. Mast Flowering and Semelparity in Bamboos: The Bamboo Fire Cycle Hypothesis. Am. Nat. 154, 383-391. https://doi.org/10.1086/303243

Milesi, F.A., Guichón, M.L., Monteverde, M.J., Piudo, L., Sanguinetti, J., 2017. Ecological consequences of an unusual simultaneous masting of Araucaria araucana and Chusquea culeou in North-West Patagonia, Argentina. Austral Ecol. 42, 711-722. https://doi.org/10.1111/aec.12489

Monadjem, A., Mahlaba, T.T.A., Dlamini, N., Eiseb, S.J., Belmain, S.R., Mulungu, L.S., Massawe, A.W., Makundi, R.H., Mohr, K., Taylor, P.J., Eiseb, Seth, J., 2011. Impact of crop cycle on movement patterns of pest rodent species between fields and houses in Africa. Wildl. Res. 38, 603-609. https://doi.org/10.1071/WR10130

Mwanjabe, P.S., Sirima, F.B., Lusingu, J., 2002. Crop losses due to outbreaks of Mastomys natalensis (Smith, 1834) Muridae, Rodentia, in the Lindi Region of Tanzania. Int. Biodeterior. Biodegradation 49, 133-137. https://doi.org/10.1016/S0964-8305(01)00113-5

Nadgauda, J.R., 2002. Bamboo flowering and famine. Curr. Sci. 82, 261-262.

Nag, S., 1999. Bamboo, Rats and Famines: Famine Relief and Perceptions of British Paternalism in the Mizo Hills (India). Environ. Hist. Camb. 5, 245-252.

Nag, S., 2008. Pied Pipers in North-East India: Bamboo-flowers, Rat-famine and the Politics of Philanthrophy (1881-2007). New Delhi.

Palis, F.G., Singleton, G.R., Brown, P.R., Huan, N.H., Umali, C., Nga, N.T.D., 2011. Can humans outsmart rodents? Learning to work collectively and strategically. Wildl. Res. 38, 568-578. https://doi.org/10.1071/WR10226

Sage, R.D., Pearson, O.P., Sanguinetti, J., Pearson, A.K., 2007. Ratada 2001: A Rodent Outbreak Following the Flowering of Bamboo (Chusquea Culeou) in Southwestern Argentina, in: Kelt, D., Kaspin, D. (Eds.), The Quintessential Naturalist. University of California Press, Davis, CA, USA, pp. 177-224.

Singleton, G.R., 2002. Non-chemical Control of Rodents in Lowland Irrigated Rice Crops. ACIAR Res. Notes 1-8. 
Singleton, G.R., Belmain, S., Brown, P.R., Aplin, K., Htwe, N.M., 2010a. Impacts of rodent outbreaks on food security in Asia. Wildl. Res. 37, 355. https://doi.org/10.1071/WR10084

Singleton, G.R., Belmain, S.R., Brown, P.R., Hardy, B., 2010b. Rodent Outbreaks: Ecology and Impacts. Int. Rice Res. Inst., Los Banos, Philippines.

Singleton, G.R., Brown, P.R., Jacob, J., Aplin, K.P., 2007. Unwanted and unintended effects of culling: A case for ecologically-based rodent management. Integr. Zool. 2, 247-59. https://doi.org/10.1111/j.1749-4877.2007.00067.x

Singleton, G.R., Brown, P.R., Pech, R.P., Jacob, J., Mutze, G.J., Krebs, C.J., 2005a. One hundred years of eruptions of house mice in Australia - a natural biological curio. Biol. J. Linn. Soc. 84, 617-627. https://doi.org/10.1111/j.10958312.2005.00458.x

Singleton, G.R., Jacob, J., Krebs, C.J., 2005b. Integrated management to reduce rodent damage to lowland rice crops in Indonesia. Agric. Ecosyst. Environ. 107, 75-82. https://doi.org/10.1016/j.agee.2004.09.010

Singleton, G.R., Sudarmaji, Brown, P.R., 2003. Comparison of different sizes of physical barriers for controlling the impact of the rice field rat, Rattus argentiventer, in rice crops in Indonesia. Crop Prot. 22, 1-7. https://doi.org/10.1016/S0261-2194(02)00060-1

Singleton, G.R., Suriapermana, S., Sudarmaji, Suriapermana, S., Sudarmaji, Suriapermana, S., 1998. An experimental field study to evaluate a trap-barrier system and fumigation for controlling the rice field rat, Rattus argentiventer, in rice crops in West Java. Crop Prot. 17, 55-64. https://doi.org/10.1016/S02612194(98)80013-6

Stephenson, P.J., 1994. Seasonality effects on small mammal trap success in Madagascar. J. Trop. Ecol. 10, 439-444. https://doi.org/10.1017/S0266467400008117

Swanepoel LH, Swanepoel CM, Brown PR, Eiseb SJ, Goodman SM, Keith M, Kirsten F, Leirs H, Mahlaba TaAM, Makundi, R. H., 2007 : A systematic review of rodent pest research in Afro-Malagasy small-holder farming systems: Are we asking the right questions? PLOS ONE, 12(3):e0174554.

Wang, D., Li, Q., Li, K., Guo, Y., 2017. Modified trap barrier system for the management of rodents in maize fields in Jilin Province, China. Crop Prot. 98, 172-178. https://doi.org/10.1016/J.CROPRO.2017.03.025 